changes in renal elimination of enalapril may contribute to the fall in pressure. ${ }^{16}$

What can be done to minimise the chance of hypotension after the first dose, and if it occurs how should it be managed? In patients with heart failure who are taking diuretics it is rarely practicable to stop the diuretics. If they cannot be stopped then reducing the dose for 24-28 hours before giving the angiotensin converting enzyme inhibitor may be prudent. Patients at high risk should be closely supervised in hospital. Enalapril should be started in elderly patients at a dose of 2.5 mg or lower. Alternatively captopril $6.25 \mathrm{mg}$ may be preferred because of its shorter duration of effect.

If severe hypotension does occur patients should, if they can tolerate it, have their heads tilted down and their legs raised and should be given intravenous crystalloid while their central venous or right heart pressures are monitored. Atropine has been useful in some patients and may be worth trying if the heart rate is low..$^{14}$ Intravenous infusion of angiotensin II has been recommended, but this agent does not have a product licence in Britain and is not readily available. ${ }^{11}$ At present it cannot be recommended for routine use. There is no justification for using other intravenous pressor agents, catecholamines, or vasopressin.

Angiotensin converting enzyme inhibitors are an important new treatment for heart failure and hypertension in the elderly. Postmarketing surveillance has not highlighted important problems with these drugs, ${ }^{617}$ but if angiotensin converting enzyme inhibitors are to be more widely used in older patients practitioners must be aware of potential adverse effects, including renal damage and marrow suppression, which may be dose related. Both captopril and enalapril are eliminated by the kidney, and both age and cardiovascular disease can impair renal function, thus increasing the potential for adverse reactions.

Regius Professor of Materia Medica,

JOHN L REID

University of Glasgow,

Stobhill General Hospital,

Glasgow G2 3UW

1 Atkinson B, Robertson JIS. Captopril in the treatment of clinical hypertension and heart failure. Lancet 1979;ii:836-9.

2 Edwards CRW, Padfield PL. Angiotensin converting enzyme inhibitors: past, present and bright future. Lancet 1985; i:30-4.

3 Consensus Trial Study Group. Effects of enalapril on mortality in severe congestive heart failure: results of the North Scandinavian enalapril survival study. N Engl f Med 1987;316:1429-34.

4 Buhler FR. Age and cardiovascular response: determinants of an antihypertensive treatment concept primarily based on beta blockers and calcium entry blockers. Hypertension 1983;5: (Suppl 2):94-100.

5 Jenkins AC, Knill JR, Dreslinski GR. Captopril in the treatment of the elderly hypertensive patient. Arch Intern Med 1985;145:2029-31.

6 Forette F, Handfield-Jones R, Henry-Amar M, et al. Traitment de l'hypertension arterielle du sujet age par un inhibiteur de l'enzyme de conversion: enalapril. Presse Med 1985;14:2237-9.

7 Arr SM, Woollard ML, Fairhurst G, Pippen CAR, Rao SK, Cooper WD. Safety and efficacy of enalapril in essential hypertension in the elderly. Br $\mathcal{Y}$ Clin Pharmacol 1985;20:279-80P.

8 Woo J, Woo KS, Vallence-Owen J. Captopril versus hydrochlorothiazide/triamterene in mild to moderate hypertension in the elderly. Lancet 1986;ii:924.

9 Croog SH, Levine S, Testa MA, et al. The effects of antihypertensive drugs on the quality of life. N Engl f Med 1986;314:1657-64.

10 Man in't Veld AJ, Schicht IM, Derkx FHM, deBruyen JHB, Schalekamp MADH. Effects of an angiotensin converting enzyme inhibitor (captopril) on blood pressure in anephric subjects. $\mathrm{Br}$ Med $\mathcal{F}$ 1980;280:288-90.

11 Hodsman GP, Isles CG, Murray GD, Usherwood TP, Webb DJ, Robertson JIS. Factors related to first dose hypotensive effect of captopril: prediction and treatment. BrMed f 1983;286:832-4.

12 Cleland JF, Semple P, Hodsman P, Ball S, Ford T, Dargie H. Angiotensin II levels, haemodynamic and sympathoadrenal function after low dose captopril in heart failure. $A m \mathcal{J}$ Med 1984;77:880-6.

13 Webster J, Newnham DM, Petrie JC. Initial dose of enalapril in hypertension. Br Med $\mathcal{J}$ 1985;290:1-4.

14 Cleland JGF, Dargie HJ, McAlpine H, et al. Severe hypotension after first dose of enalapril in heart failure. BrMed f 1985;291:1309-11.

15 Ajayi AA, Hockings N, Reid JL. Age and the pharmacodynamics of angiotensin converting enzyme inhibitors, enalapril and enalaprilat. Br f Clin Pharmacol 1986;21:349-57.

16 Hockings N, Ajayi AA, Reid JL. Age and the pharmacokinetics of angiotensin converting enzyme inhibitors, enalapril and enalaprilat. Brf Clin Pharmacol 1986;21:341-8.

17 Cooper WD, Sheldon D, Brown P, Kimber GR, Isitt VL, Currie WJC. Post-marketing surveillance of enalapril: experience in 11710 hypertensive patients in general practice. $f R$ Coll Gen Pract 1987;37:346-9.

\section{Haemophilia, AIDS, and no fault compensation}

About 1200 British haemophiliacs have been infected with the human immunodeficiency virus (HIV) from the transfusion of factors VIII or IX. So far 60 have developed the acquired immune deficiency syndrome (AIDS), and 45 have died. The prognosis for the remainder is uncertain, but the signs are ominous. Denial of insurance and mortgage protection because of their infection means that most have no hope of providing for their widows and dependent children. Because of this the main thrust of the Haemophilia Society campaign launched this week is to ask the government to ensure that the family home is protected and that dependants receive a weekly non-means tested hardship allowance. The society also asks that haemophiliacs should be granted a disability premium to replace single payments and that this should be high enough to cover the costs of coping with problems related to $\mathrm{HIV}$ in addition to the underlying bleeding disorder.

In 1978 the Royal Commission on Civil Liability and Compensation for Personal Injury (the Pearson commission) put forward reasons why a no fault scheme for medical accidents should not be introduced in Britain. ${ }^{1}$ The commission admitted that some members thought that the arguments for and against such a scheme were finely balanced. A decade later reappraisal of the reasons for rejection shows that none apply to the small and finite number of haemophiliacs presently appealing for compensation from the government because of iatrogenic infection with the human immunodeficiency virus (HIV). On the contrary, one of the arguments for introducing a no fault scheme was that "blood products may be used which contain viruses the presence of which could not be foreseen."

The government response to earlier requests for help was that individual members should go to law in an attempt to establish negligence. It soon became clear, however, that legal opinion in both Britain and the United States was that claims for negligence against prescribing doctors, health authorities, or those companies that manufacture factors VIII or IX were unlikely to succeed. Haemophiliacs thus had to appeal to the government to be made a special case. The main difficulty that the Pearson commission saw with no fault compensation was establishing causation, "since the cause of many injuries could not be identified." In the case of the haemophiliacs causation is, of course, clear and unequivocal. The commission also thought there would be difficulty in distinguishing a medical accident from the natural progression of a disease or injury and from a foreseeable side effect of treatment; it worried, too, about adjudicating and administering a general no fault scheme. It envisaged prohibitive costs and difficulties in dealing with medical accidents occurring in private practice.

These difficulties should not arise with haemophiliacs as they are a readily defined group already known to haemophilia centre directors. Further, most are already receiving state benefits because of their primary disorder and therefore are also known to senior staff of the Department of Health and Social Security. The facts that haemophiliacs are well known and small in number must surely make administering a special scheme to help them straightforward and safe from abuse.

The new argument that the government has against the scheme is the difficulty in differentiating between haemo- 
philiacs and other groups suffering harm from necessary medical treatment. A possible answer to this problem may lie in one outcome of the Pearson commission-could not the Vaccine Damage Payments Act of 1979 include haemophiliacs?

There now seems to be consensus both in parliament and in the community that special help should be afforded to those with haemophilia and to the few people infected from contaminated blood transfusion or organ grafting. Both the reasoning behind the Pearson commission's decision on no fault compensation and the wording of the Vaccine Damage Payments Act seem to provide the government with ways forward. Following the Pearson commission is probably the best option, although the Vaccine Damage Payments Act does provide for help for children or third parties injured because of the initial damage and would thus cover the needs of affected families as well as those of the haemophiliacs themselves. Either way, the need for action is urgent, and the government must stop prevaricating and act swiftly to mitigate the distress of haemophiliacs and their families.

\section{Peter Jones}

Director,

Haemophilia Centre,

Royal Victoria Infirmary

Newcastle upon Tyne NE1 4LP 1 Royal Commission on Civil Liability and Compensation for Personal Injury. Report. London:
HMSO, 1978 .
2 House of Commons Social Services Committee. Problems associated with AIDS. London: HMSO,
1987.

\section{Beware cocaine}

A century ago Sigmund Freud wrote "a song of praise to this magical drug [cocaine]" and described it as a "wonderful remedy." Since then cocaine has been thought of as both one of the most dangerous and addictive substances known to man and a harmless (or even beneficial) recreational drug. We now need to reassess what we know about cocaine because increasing amounts of the drug have been available in Britain since the 1970s. Some American commentators foresee a tidal wave of cocaine addiction sweeping across the Atlantic. This prediction may or may not come true: lysergide (LSD) travelled quickly across the Atlantic in the 1960s, whereas phencyclidine hydrochloride (angel dust) in the 1970s did not. But there is every cause for concern because of the massively increased production of the drug in South America and the increasing professionalisation of those trading illicitly in the drug.

Other reasons for reassessment are the changes in the preparations of cocaine being used and in the way they are taken. As well as cocaine hydrochloride crystals, which are often sniffed or occasionally injected, additions to the menu are cocaine paste, "crack," and freebase. These chemically modified versions of cocaine are worrying because they can be smoked or inhaled, producing rapid rises in blood concentration and a powerful subjective "hit." They are thus more likely to produce dependence than cocaine when sniffed. In some users cocaine quickly produces a powerful dependence. Laboratory animals may inject themselves with cocaine in preference to food and continue to do so until exhausted or dead..$^{23}$ While some users can keep their use of cocaine under control, others become as dependent as heroin addicts or alcoholics. Indeed, cocaine may have greater potential than heroin for producing dependence. There is no way of predicting whether a person will be able to maintain control or will become dependent. People who become dependent take larger doses increasingly often and so increase the associated health risks.

Some of the adverse effects on health of cocaine are minor, such as damage to the nose, but the drug can also kill. Cocaine has precipitated acute myocardial infarction, ventricular tachycardia and fibrillation, myocarditis, and sudden death even in "recreational" users who do not use the drug intravenously. ${ }^{4}$ The drug increases blood pressure, and many people who are otherwise at low risk of cardiovascular accident are exposed to a greatly increased risk. Death may result from cardiac or, more often, respiratory arrest. High doses may also cause seizures, and among hundreds of cocaine users who telephoned an American "cocaine hotline" $14 \%$ described seizures with loss of consciousness.

Intranasal use of the drug produces vasoconstriction of the mucous membranes followed by vasodilatation when the drug effect wears off; this often leads to acute and chronic rhinitis and possibly chronic sinusitis. Bleeding and ulceration of the nasal mucosa are also common; perforation of the septum is rare, though it is sufficiently dramatic to have received much publicity. Those who smoke either freebase or cocaine hydrochloride often complain of sore throats, chest pain, and black or bloody sputum. The damage may be caused by the high temperature of the inhaled cocaine fumes. Poorly prepared freebase and cocaine paste may also damage the lungs because of the corrosive chemicals used to process the drug. The dangers of intravenous injection ought by now to be sufficiently obvious not to need amplification.

Like the amphetamines, cocaine stimulates the central nervous system and can cause a florid, short lived psychotic reaction with delusions, paranoia, and hallucinations. This generally follows persistent binges with the drug or the use of high doses, though single episodes with low doses can also lead to an acute anxiety reaction with high blood pressure, racing heart, anxiety, and paranoid ideation. Many cocaine users take sedative and hypnotic drugs to reduce the "jitters" caused by cocaine or to relieve the unpleasant "crash" after the euphoria wears off.

The potential risks of taking cocaine are thus great, but the actual health risks have unfortunately been exaggerated in some recent discussions. There is no need for exaggeration. Cocaine is not a safe recreational drug: its dangers are too many and too great.

MichaEL Gossop

Director of Research,

Drug Dependence Clinic Research and

Treatment Unit,

Bethlem Royal Hospital,

Beckenham BR3 3BX

1 Gossop M. Living with drugs. Aldershot: Wildwood, 1987.

2 Deneau G, Yanagita T, Seevers MH. Self-administration of psychoactive substances by the monkey. Psychopharmacologia 1969;16:30-48.

3 Johanson CE, Balster RL, Bonese K. Self-administration of psychomotor stimulant drugs: the effects of unlimited access. Pharmacol Biochem Behav 1976;4:45-51.

4 Isner JM, Estes M, Thompson PD, et al. Acute cardiac events temporally related to cocaine abuse. N Engl f Med 1986;315:1438-43.

5 Gold MS, Dackis CA, Pottash A, Extein I, Washton A. Cocaine update; from bench to bedside. In: Stimmel B, ed. Controversies in alcoholism and substance abuse. New York: Haworth, 1986:35-60. 